\title{
Economic Performance and Financial Conditions Index Nexus: Evidence from Selected Sub-Saharan African Countries
}

\author{
Ogbonna Udochukwu Godfrey ${ }^{1}$, Ejem Chukwu Agwu ${ }^{2,}$, \\ ${ }^{1}$ Department of Management Science, Rhema University, Aba, Nigeria \\ ${ }^{2}$ Department of Banking and Finance, Abia State University, Uturu, Nigeria
}

Email address:

ecjah71@yahoo.com (E. C. Agwu)

${ }^{*}$ Corresponding author

\section{To cite this article:}

Ogbonna Udochukwu Godfrey, Ejem Chukwu Agwu. Economic Performance and Financial Conditions Index Nexus: Evidence from Selected Sub-Saharan African Countries. Journal of Finance and Accounting. Vol. 8, No. 3, 2020, pp. 158-164. doi: $10.11648 /$ j.jfa.20200803.17

Received: May 7, 2020; Accepted: May 25, 2020; Published: June 17, 2020

\begin{abstract}
The purpose this study is to construct a financial conditions index for six sub-Saharan African Countries; namely, Nigeria, South Africa, Namibia, Mauritius, Kenya and Ghana, within the dynamic panel data framework using annual data covering from 2009 to 2018. The variables included in the construction of the index are treasury bills rate, real effective exchange rate, interest rate spread, credit to private sector ratio to Gross Domestic Product and value of stocks traded. The weights attached to these variables in the construction of the financial conditions index are estimated using the dynamic fixed effects coefficients, while the predictive power of the constructed index is evaluated within the dynamic panel General Method Moment framework. The output of analysis found that while real GDP per capita growth is not significantly related to real effective exchange rate, interest rate spread and credit to private sector ratio to Gross Domestic Product, it is significantly related to treasury bills rate and value of stocks traded. Thus, the effectiveness of monetary policy in the selected sub-Saharan countries depends only on money market and capital market conditions. Also results show that in Namibia, Ghana, Kenya and Nigeria, the financial conditions have been tighter than the prevailing macroeconomic conditions, while South Africa's financial conditions have been looser than its prevailing macroeconomic conditions. However, Mauritius' financial conditions have been neither tighter nor looser than its prevailing macroeconomic conditions. In the light of the above, the researchers suggest that the focus of monetary policy in the selected sub-Saharan countries has been to reduce inflation.
\end{abstract}

Keywords: Financial Conditions Index, Inflation, GDP Per Capita

\section{Introduction}

Interest in financial conditions index as a good predictor of future economic performance started since 2000s, yet there is little understanding on how it works. Earlier, scholars and policy makers relied heavily on monetary conditions indexes developed in the 1990 s to evaluate the effect of monetary policy shocks on real economy. However, monetary conditions indexes accommodate only monetary variables such as short-term interest rate and exchange rate, hence may not accurately predict real economic variables such as inflation and growth rate. This is because other financial variables such as asset prices and property prices also affect economic performance and are correlated with monetary policy [20].

Financial conditions index is a natural extension of monetary conditions index and a more comprehensive index that incorporates financial market frictions that impair the effectiveness of monetary policy [4]. Thus, financial conditions indexes can provide a more accurate prediction of future economic performance.

The main purpose of this paper is to construct financial conditions index for selected sub-Saharan African countries and its predictive ability for real economic variables using the dynamic panel generalized method of moment (GMM) framework. 
The remainder of this study has the following structure: The next section reviews the extant literature on financegrowth relationship as well as financial conditions index. Section 3 describes the data, models and methods; section 4 contains empirical analysis and discussion while the study is concluded in section 5 .

\section{Literature Review}

\subsection{Theoretical Framework}

The relationship between indicators of financial conditions and real economic variables can be described within the framework of supply leading theory of finance-growth relationship. This theory, which can be traced to the influential works of Schumpeter [19], implies that economic growth results from the activities in the financial institutions and markets that are directly influenced by the decisions of the monetary authorities. The monetary policy transmission mechanism states that monetary authorities influence the real economy through financial variables such as interest rates, exchange rate, credit supply and asset prices. Also, the financial resources mobilized by the financial sector are put into productive use by economic agents, hence financial development triggers economic growth.

The supply-leading theory has also gained wide acceptance in the literature as many empirical studies have confirmed its plausibility in explaining the finance-growth nexus using data obtained from different countries and regions and at different frequencies. Further, several studies have also relied on the empirical models implied by this theory to construct financial conditions indexes for different countries and examine their predict power for future economic growth and inflationary pressure.

\subsection{Review of Empirical Studies}

Previous studies in Nigeria suggest that financial conditions variables have a significant effect on economic growth in Nigeria both in the short run and in the long run. Also, credit to private sector and stock market index are the most significant factors for nominal GDP, hence have the highest weights in the construction of the financial conditions index. This evidence is, therefore, consistent with both credit and asset price channels of monetary policy transmission mechanism. This finding also agrees with the supply leading theory of finance-growth relationship as well as several previous studies including $[1,3,10,18,11,16]$.

Also, Swiston [20] use a VAR model and the implied impulse-response functions to construct a financial conditions index for the US. Their results show that credit availability sis an important driver of the business cycle and contributes more than $20 \%$ of the typical contribution of financial sector variables to economic growth. Their results also show that the constructed financial conditions index is a useful predictor for real GDP growth.

Balcilar, Thompson, Gupta and Van Eyden [7] employed a nonlinear logistic smooth transition vector autoregressive model (LSTVAR) to examine the nonlinear asymmetric effect of financial conditions on economic performance in South Africa. They use a previously constructed financial conditions index comprising sixteen financial variables. They find that financial conditions shocks have a nonlinear effect on real economic variables, and that the impact of financial shocks on both growths in manufacturing output and Treasury bill rates is more pronounced during pickups. However, the effect of financial conditions shocks is more significant for inflation during recessions.

Aikman, Lehnert, Liang and Modugno [2] examined the effect of private nonfinancial credit on the dynamic impact of financial conditions and monetary policy on macroeconomic performance in US from 1975 to 2014 using a threshold vector autoregression model. Their results show that private nonfinancial credit has a nonlinear effect on the dynamic relationship both financial conditions and monetary policy on the real economy.

Auer [6] employed employs a dynamic factor model to construct financial conditions indexes for Hungary, Poland and Czech Republic using time series data measured at monthly frequency from 2001M01 to 2016M11. The results provide strong evidence that financial conditions index contains quality information about the future economic performance in the three Central and Eastern European countries.

Aramonte, Rosen and Schindler [5] examined the onemonth ahead and one-quarter ahead predictive power of financial conditions indexes for stock market returns and macroeconomic variables (credit availability, housing market and manufacturing activity) in US using OLS techniques with heteroskedasticity standard errors and Granger causality tests. They find that financial conditions have a weak predictive power at the selected horizons. However, the predictability of the indexes improves when the 2008 global financial crisis is incorporated in the predictive model.

Wang, $\mathrm{Xu}$ and Chen [21] used monthly data from $2002 \mathrm{M} 01$ to $2015 \mathrm{M} 01$ to construct a financial conditions index for China as well as examine its effect on inflation. Based on a time-varying factor augmented vector autoregressive models with stochastic volatility, they find that the constructed financial conditions index can accurately predict future inflation.

Giri and Bansod [9] used quarterly data from 1991Q12 to 2015Q4 to construct a financial conditions index for India and examine its cointegrating relationship with economic growth. While the principal component analysis is used to construct the financial condition index, its cointegrating relationship with economic growth is examined using the ARDL-ECM approach. The summary of their findings is that financial conditions have a long run predictive power for economic growth.

Balfoussia and Gibson [8] examined the sensitivity of investment to cash flows varies with overall financial conditions using firm-level panel data for 2400 listed 
companies in euro area countries from 1980 to 2013. The results from fixed effects regression suggest that financial conditions significantly moderate the investment-cash flow relationship.

Khundrakpam, Kavediya and Anthony [13] constructed financial condition indices for India and evaluated their ability to predict business cycle. They examined whether financial conditions index constructed based on principal component analysis (PCA) can predict economic growth rate better than financial conditions index constructed based on vector autoregressive (VAR) model. Their results show that PCA-based financial conditions index outperforms VARbased financial conditions index.

Kabundi and Mbelu [12] constructed a financial conditions index for South Africa using monthly time series data January 2000 to April 2017. They also specified and estimated a three-factor time-varying parameter factoraugmented vector autoregressive (TVP-FAVAR) model incorporating financial conditions index, headline inflation and GDP growth rate. They found amongst others that tighter financial conditions reduce both economic growth rate and level of inflation.

Ncanywa and Mabusela [14] used the dynamic panel ARDL framework to test the link between financial development and economic growth in five sub-Saharan African countries; namely, Ghana, Kenya, Botswana, Nigeria and South Africa, using yearly data from 1980 to 2014. They found the presence of both short run and long run relationship between financial development and economic growth, with credit to private sector and bank liquid liabilities both exerting a positive long run effect on economic growth, while domestic savings exerts a negative effect.

Olayungbo and Quadri [17] applied both the Pooled Mean Group ARDL framework to model the relationship between financial development and economic growth incorporating the both the direct and interaction effect of remittances. The study focuses on sub-Saharan countries and is based on yearly data for 20 countries from 2000 to 2015 which were collected from the World Development Indicators data based. They found amongst others that both financial development and remittances exhibit a positive effect on economic growth.

Recently, Okunlola, Masade, Folaranmi Lukman and Ajayi Abiodun [15] investigated the finance-growth nexus in Nigeria using the causality framework developed by Toda and Yamamoto (1995) which is based on augmented VAR. Based on yearly data from 1985 to 2015 collected from CBN, NBS and NSE, they find evidence supporting the supplyleading theory which asserts that the level of financial development matters for economic growth.

\section{Methodology}

\subsection{Data Description}

The data used in this study comprise yearly panel observations for six sub-Saharan African countries from 2009 to 2018. The countries are Nigeria, South Africa, Namibia, Mauritius, Kenya and Ghana, while the variables are real GDP per capita, real GDP per capita growth rate, inflation rate, treasury bills rate, real effective exchange rate, interest rate spread (the difference between prime lending rate and monetary policy rate), credit to private sector ratio to GDP and value of stocks traded. The data are collected from World Development Indicators and the Central Banks of the individual countries. All empirical analyses are done in EViews.

The descriptive statistics for the selected variables are presented in Table 1.

Table 1. Descriptive Statistics.

\begin{tabular}{|c|c|c|c|c|c|c|}
\hline Variable & $\bar{x}$ & $\boldsymbol{\sigma}$ & $S$ & $K$ & JB & P-value (JB) \\
\hline GDPPCGR & 2.30 & 2.69 & 0.08 & 4.02 & 2.68 & 0.2600 \\
\hline GDPPC & 4661.60 & 3183.21 & 0.35 & 1.67 & 5.68 & 0.0600 \\
\hline INFL & 7.80 & 4.33 & 0.85 & 2.95 & 7.19 & 0.0300 \\
\hline TBR & 8.92 & 5.59 & 1.34 & 4.37 & 22.66 & 0.0000 \\
\hline REER & 100.31 & 16.08 & -0.38 & 2.48 & 2.09 & 0.3500 \\
\hline SPREAD & 5.12 & 3.17 & 1.60 & 4.73 & 33.10 & 0.0000 \\
\hline CPSR & 58.95 & 48.24 & 0.78 & 2.18 & 7.72 & 0.0200 \\
\hline VST & 57500000000.00 & 116000000000.00 & 1.77 & 4.73 & 31.82 & 0.0000 \\
\hline
\end{tabular}

\subsection{Methods}

To the estimate the relative impact of each financial variable on growth, we employ the dynamic panel effects method. Compared to static panel data methods, this method has the advantage of estimating the effect of lagged dependent variable, the coefficients on the included financial variables as well as the unobserved country-specific effects that are likely to correlate with those coefficients.

We specify our dynamic panel data model as follows:

$$
\operatorname{LGDPPCGR}_{i, t}=\beta_{0}+\gamma_{i}+\beta_{1} L G D P P C G R_{i, t-1}+\beta_{2} L T B R_{i, t}+\beta_{3} L R E E R_{i, t}+\beta_{4} L S P R E A D_{i, t}+\beta_{5} L C P S R_{i, t}+\beta_{6} L_{V S T} T_{i, t}+\epsilon_{i, t}
$$

Where $\beta_{0}$ is the regressions intercept, $\gamma_{i}$ is the unobserved country-specific effects, $\beta_{1}$ is the coefficient on lagged dependent variable, $\beta_{2}, \beta_{3}, \ldots, \beta_{6}$ are the coefficients on the financial conditions components, $\epsilon_{i, t}=$ error term.

To construct the financial conditions index, we use the following formula. 


$$
F C I=\sum_{j=1}^{n} w_{j}\left(x_{j, t}-\overline{x_{j}}\right)
$$

Where $\mathrm{FCI}=$ financial conditions index, $x_{j, t}=$ financial conditions variable $j$ at time $t, \overline{x_{j}}=$ mean of $x_{j}$ and $w_{j}$ is the weight associated with each financial variable. Here, $x_{j}$ includes treasury bills rate (TBR), real effective exchange rate (REER), interest rate spread (SPREAD), credit to private sector ratio to GDP (CPSR) and value of stocks traded (VST).
To examine whether the constructed financial conditions index can predict economic performance, we employ dynamic Panel Generalized Method of Moment (GMM) framework using the Arellano-Bond first difference approach. This method has the advantage of controlling both heterogeneity and endogeneity biases. Our Panel GMM models for real GDP per capita and inflation rate are given as follows:

$$
\begin{gathered}
\triangle L G D P P C_{i, t}=\lambda_{1} \Delta G D P P C_{i, t-1}+\lambda_{1} \Delta F C I_{i, t}+\lambda_{1} \Delta L I N F L_{i, t}+\varepsilon_{1, t} \\
\triangle L I N F L_{i, t}=\psi_{1} \Delta L I N F L_{i, t-1}+\psi_{1} \Delta F C I_{i, t}+\psi_{1} \Delta L G P D P \backslash C_{i, t}+e_{1, t}
\end{gathered}
$$

To control for endogeneity biases, we use the all valid lagged dependent variable from period 2 as instrumental variables.

\section{Empirical Results}

\subsection{Financial Conditions Indicators and Growth}

Table 2 shows the dynamic fixed effects estimates for the finance-growth relationship; the fixed effects method is selected based on Likelihood ratio test. Table 3 shows the model fit statistics and diagnostic tests. Table 4 shows the country-specific fixed effects.

From Table 2, we can see that consistent with previous studies, $\beta_{1}$, which captures the effect of lagged GDP per capita growth rate, has an estimated value of 0.2875 and a p-value of 0.0122 , showing that previous per capita GDP growth has a positive and significant effect on current GDP per capita growth. If growth rate increases by $1 \%$ in the current year, there would be, on average, an increase in growth rate by approximately $0.29 \%$ in the next one year, holding other explanatory factors constant. Further, the results show that although, treasury bills rate $\left(\beta_{2}=\right.$ $-2.3182, p$-value $=0.0098)$ is the most significant financial factor for economic growth, it is associated with a negative sign, indicating that it exerts an adverse effect on economic growth. Similarly, the beta on credit to private sector ratio to $\operatorname{GDP}\left(\beta_{5}=-1.0431, p\right.$-value $=$ 0.7070 ) is negatively signed, although, not statistically significant. This implies that an increase in private sector credit relative to GDP would contemporaneously lead to a decrease in growth rate. On the contrary, however, real effective exchange rate $\left(\beta_{3}=1.3937, p\right.$-value $\left.=0.6062\right)$, interest rate $\operatorname{spread}\left(\beta_{4}=0.1655, p\right.$-value $\left.=0.8464\right)$ and value of stocks traded $\left(\beta_{6}=1.5142, p\right.$-value $\left.=0.0129\right)$ all have a positive relationship with real GDP per capita growth. However, only the effect of value of stocks traded is statistically significant. The Wald statistic ( $p$-value = 0.0000 ) is highly significant, indicating that treasury bills rate, real effective exchange rate, interest rate spread, credit to private sector ratio to GDP and value of stocks traded all have a highly significant joint effect on real GDP per capita growth.

From Table 3, the estimated fixed effects model fits very well to the panel data, with the Adj. $R^{2}$ being a little above $70 \%$ and the F-statistic being highly significant. The Durbin
Watson statistic is close to 2 and the cross sections dependence test ( $\mathrm{p}$-value $=0.1641$ ) is insignificant. Thus, there is no specification problem in the estimated model.

From Table 4, there are significant cross-sectional variations in the estimated fixed effects, with GHANA $\left(\gamma_{6}=8.0653\right)$, NAMIBIA $\left(\gamma_{3}=6.9646\right)$, MAURITIUS $\left(\gamma_{4}=1.8547\right)$ and KENYA $\left(\gamma_{5}=1.4382\right)$ having positive country-specific factor, while NIGERIA $\left(\gamma_{1}=-2.6071\right)$, and SOUTH AFRICA $\left(\gamma_{2}=-7.8200\right)$ have negative country-specific factors. The Likelihood ratio statistic has a probability of 0.0006 , showing that the observed crosssectional differences in country-specific factors are highly significant.

Overall, the dynamic fixed effects results suggest that supply-leading theory of Schumpeter [19] governs the relationship between financial variables and economic growth in sub-Saharan African countries.

Table 2. Fixed Effects Result.

\begin{tabular}{lll}
\hline Coefficient & Estimate & P-value \\
\hline$\beta_{0}($ INTERCEPT) & -28.694 & 0.1602 \\
$\beta_{1}($ GDPPCGR $(-1))$ & 0.2875 & 0.0122 \\
$\beta_{2}$ (TBR) & -2.3182 & 0.0098 \\
$\beta_{3}(\mathrm{REER})$ & 1.3937 & 0.6062 \\
$\beta_{4}(\mathrm{SPREAD})$ & 0.1655 & 0.8464 \\
$\beta_{5}(\mathrm{CPSR})$ & -1.0431 & 0.7070 \\
$\beta_{6}(\mathrm{VST})$ & 1.5142 & 0.0129 \\
Wald statistic & 22.1306 & 0.0005 \\
\hline
\end{tabular}

Table 3. Model Goodness of Fit and Diagnostic Tests.

\begin{tabular}{ll}
\hline$R^{2}$ & 0.7849 \\
Adj. $R^{2}$ & 0.7086 \\
F-statistic & $10.284(0.0000)$ \\
Durbin Watson & 1.7907 \\
Cross sections dependence test & $20.209(0.1641)$ \\
\hline
\end{tabular}

Table 4. Model Goodness of Fit and Diagnostic Tests.

\begin{tabular}{ll}
\hline Country & Country-Specific Fixed Effects \\
\hline NIGERIA & -2.6071 \\
SOUTH AFRICA & -7.8200 \\
NAMIBIA & 6.9646 \\
MAURITIUS & 1.8547 \\
KENYA & 1.4382 \\
GHANA & 8.0653 \\
Likelihood Ratio statistic & $21.6670(0.0006)$ \\
\hline
\end{tabular}




\subsection{Constructing a Financial Conditions Index for The Selected Sub-Saharan Countries}

Figure 2 shows the financial conditions index for the selected sub-Saharan African countries using the fixed effects coefficients as weights (see Figure 1). To better understand the constructed financial conditions index, we show the country by country mean and standard deviation values in Figure 3.

From Figure 3, we can see that Namibia, Ghana, Kenya and Nigeria have a positive mean financial conditions index, indicating that the financial conditions for these countries were, on average, tighter than their prevailing macroeconomic conditions. On the contrary, South Africa has a negative mean financial conditions index which suggests that its financial conditions were, on average, looser than its prevailing macroeconomic conditions. The financial conditions index for Mauritius averaged zero, indicating that its financial conditions were neither tighter nor looser than its prevailing macroeconomic conditions.

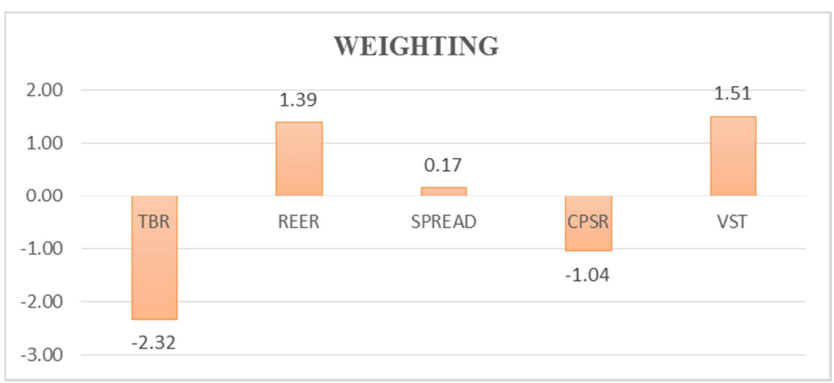

Figure 1. Weighting for Financial Conditions Index.

$\mathrm{FCl}$

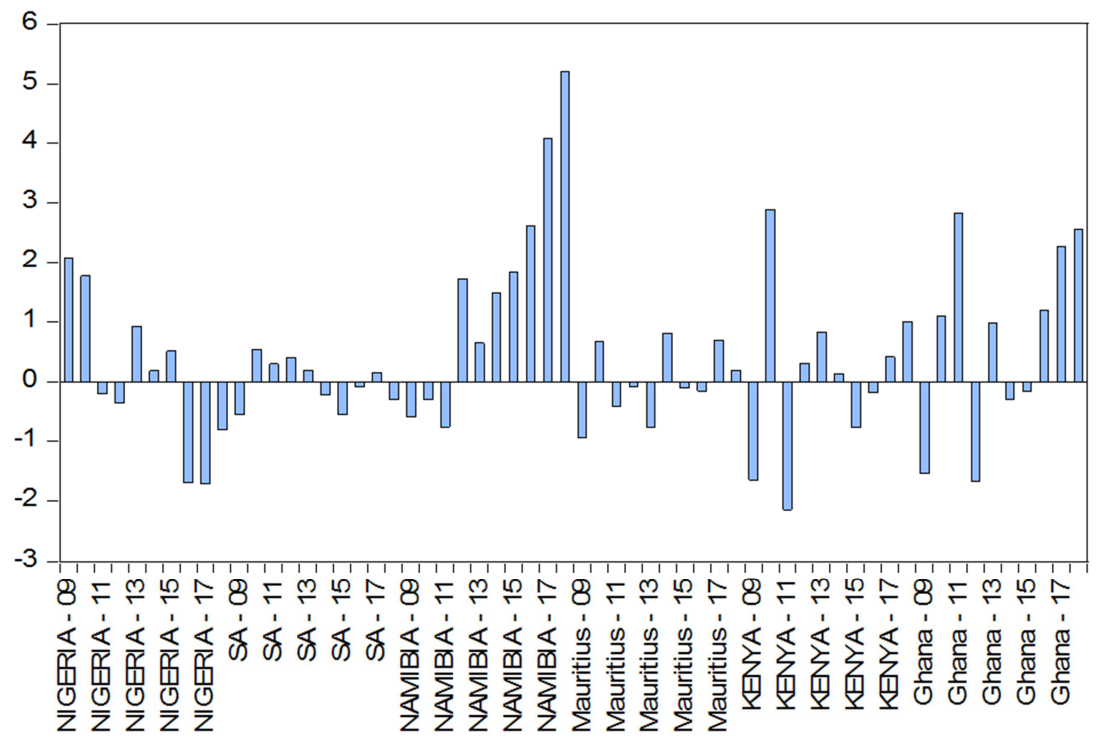

Figure 2. Financial Conditions Index for Selected Sub-Saharan Countries.

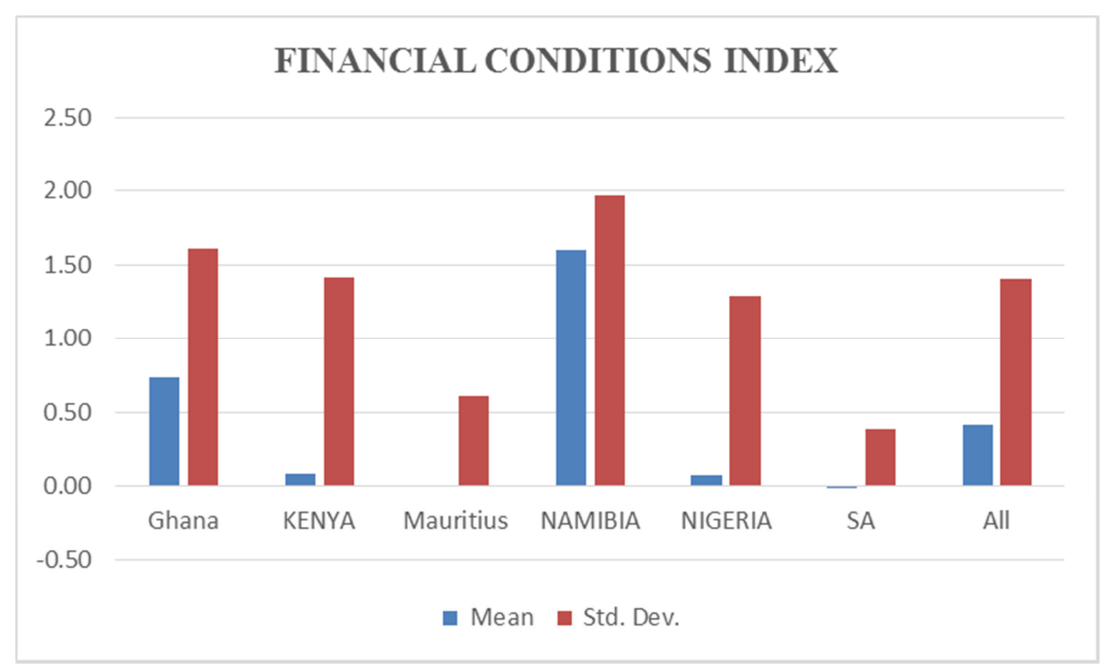

Figure 3. Country by Country Financial Conditions Index.

\subsection{Financial Conditions Index and Economic Performance}

Table 5 presents the dynamic panel GMM regression results for the predictive power of financial conditions for 
real GDP per capita and inflation rate using the ArellanoBond first difference approach. For each regression, all valid lagged dependent variables from period 2 are used as instrumental variables to control for endogeneity problem often associated with this estimation method.

Table 5. Estimated Dynamic Panel GMM Results.

\begin{tabular}{lll}
\hline Variable & Real GDP Per Capita & Inflation \\
\hline LGDPPC (-1) & $0.9087(0.00000)$ & - \\
LINFL (-1) & - & $0.4868(0.0111)$ \\
FCI & $0.0120(0.2954)$ & $-0.2009(0.0243)$ \\
LGDPPC & - & $0.2885(0.8265)$ \\
LINFL & $0.0706(0.0068)$ & - \\
Instrument Rank & 6 & 6 \\
J-statistic & $0.4567(0.9282)$ & $2.4040(0.4928)$ \\
Serial Correlation AR (1) & $-1.1476(0.2511)$ & $-6.0130(0.0000)$ \\
Serial Correlation AR (2) & $0.1477(0.8826)$ & $-0.5333(0.5938)$ \\
\hline
\end{tabular}

From Table 5, both lagged GDP per capita ( $\mathrm{p}$-value = $00000)$ and lagged inflation $(\mathrm{p}$-value $=0.0111)$ are positive and significant in their respective equations, hence they are significant determinants of their current values. Further, as expected, the coefficient on financial conditions index is correctly signed in both real GDP and inflation models. Specifically, the coefficient of 0.0120 and -0.2009 shows that improving financial conditions would improve real GDP per capita and at the same time reduce inflation rate. However, financial conditions index is not significant $(p$-value $=0.2954)$ in the real GDP per capita model, it is significant ( $\mathrm{p}$-value = 0.0243 ) at $5 \%$ level in the inflation model. Thus, there is evidence that financial conditions index can accurately predict inflation, but its predictive ability for real GDP per capita is in doubt. While these results contradict the findings of Swiston [20], Giri andBansod [9], they are consistent with the findings of Wang, $\mathrm{Xu}$ and Chen [21].

The J-statistic is not significant for the two models, indicating that shows although, our GMM models, each with an instrument rank of 6 , are overidentified, there is no statistical evidence that the overidentifying restrictions are invalid. Also, the first order Arellano-Bond serial correlation statistic has the expected negative sign for both models, though not statistically significant for real GDP model, while the second order statistic is also not statistically significant as expected. This clearly shows that the model residuals are free from serial correlation problems, hence, our GMM results are reliable.

To check the robustness of our results, we first estimate each model with a control variable and then reestimate the model without any control variable. For real GDP per capita model, inflation rate is included as a control variable, while for inflation model, real GDP per capita serves as the control variable. The results are generally the same with no significant change in terms of the sign and size of the coefficients as well as their statistical significance. Therefore, we conclude that our results are robust.

\section{Discussion and Conclusion}

The aim of this study is to construct a financial conditions index for six sub-Saharan African Countries (Nigeria, South Africa, Namibia, Mauritius, Kenya and Ghana) within the dynamic panel data framework using annual data covering from 2009 to 2018. The variables included in the construction of the index are treasury bills rate, real effective exchange rate, interest rate spread, credit to private sector ratio to GDP and value of stocks traded. The weights attached to these variables in the construction of the financial conditions index are estimated using the dynamic fixed effects coefficients, while the predictive power of the constructed index is evaluated within the dynamic panel GMM framework.

First, we find that while real GDP per capita growth is not significantly related to real effective exchange rate, interest rate spread and credit to private sector ratio to GDP, it is significantly related to treasury bills rate and value of stocks traded. Thus, the effectiveness of monetary policy in the selected sub-Saharan countries depends only on money market and capital market conditions. However, our evidence generally suggests that the relationship between financial variables and economic growth is governed by the supply-leading theory of Schumpeter [19].

Further, our results show that in Namibia, Ghana, Kenya and Nigeria, the financial conditions have been tighter than the prevailing macroeconomic conditions, while South Africa's financial conditions have been looser than its prevailing macroeconomic conditions. However, Mauritius' financial conditions have been neither tighter nor looser than its prevailing macroeconomic conditions.

Finally, our results provide evidence that financial conditions can usefully predict inflation but its predictive power for real GDP per capita is in doubt. This may suggest that the focus of monetary policy in the selected sub-Saharan countries has been to reduce inflation.

\section{References}

[1] Acaravci, A., Ozturk, I., \& Acaravci, S. K. (2007). Financegrowth nexus: Evidence from Turkey. International Research Journal of Finance and Economics, 11, 30-40.

[2] Aikman, D., Lehnert, A., Liang, N., \&Modugno, M. (2017). Credit, financial conditions, and monetary policy transmission. Brookings Institution, Hutchins Center, 39. 
[3] Al-Malkawi, H. A. N., \& Abdullah, N. (2011). Finance-growth nexus: evidence from a panel of MENA countries. International Research Journal of Finance and Economics, 63 (63).

[4] Angelopoulou, E., Balfoussia, H., \& Gibson, H. D. (2014). Building a financial conditions index for the euro area and selected euro area countries: what does it tell us about the crisis?. Economic Modelling, 38, 392-403.

[5] Aramonte, S., Rosen, S., \& Schindler, J. (2017). Assessing and combining financial condition indexes. International Journal of Central Banking, 13 (1), 1-52.

[6] Auer, S. (2017). A Financial Conditions Index for the CEE economies. Bank of Italy Temi di Discussione (Working Paper) No, 1145 .

[7] Balcilar, M., Thompson, K., Gupta, R., \& Van Eyden, R. (2016). Testing the asymmetric effects of financial conditions in South Africa: A nonlinear vector autoregression approach. Journal of International Financial Markets, Institutions and Money, 43, 30-43.

[8] Balfoussia, H., \& Gibson, H. D. (2019). Firm investment and financial conditions in the euro area: evidence from firm-level data. Applied Economics Letters, 26 (2), 104-110.

[9] Giri, A. K., \&Bansod, D. (2019). Establishing finance-growth linkage for India: a financial conditions index (FCI) approach. International Journal of Emerging Markets.

[10] Ibrahim, S., Abdullahi, A. B., Azman-Saini, W. N. W., \& Rahman, M. A. (2017). Finance-Growth Nexus: Evidence based on New Measures of Finance. International Journal of Economics \& Management, 11 (1).

[11] Ipeghan, I. Y. O., \& Marshall, E. S. (2019). Modeling Capital Market Performance Indicators, Financial Development and Economic Growth in Nigeria: Empirical Evidence.

[12] Kabundi, A., \& Mbelu, A. (2020). Estimating a time-varying financial conditions index for South Africa. Empirical Economics, 1-28.

[13] Khundrakpam, J. K., Kavediya, R., \& Anthony, J. M. (2017). Estimating Financial Conditions Index for India. Journal of Emerging Market Finance, 16 (1), 61-89.

[14] Ncanywa, T., \& Mabusela, K. (2019). Can financial development influence economic growth: The sub-Saharan analysis. Journal of Economic and Financial Sciences, 12 (1), $1-13$.

[15] Okunlola, O. A., Masade, E. O., Folaranmi Lukman, A., \& Ajayi Abiodun, S. (2020). Investigating Causal Relationship between Financial Development Indicators and Economic Growth: Toda and Yamamoto Approach. Iranian Economic Review, 24 (1), 225-246.

[16] Olaniyan, T. O. (2019). Interactive Effects of Remittances and Financial Sector Development on Economic Growth in Nigeria. Remittances Review, 4 (1), 19-39.

[17] Olayungbo, D. O., \& Quadri, A. (2019). Remittances, financial development and economic growth in sub-Saharan African countries: evidence from a PMG-ARDL approach. Financial Innovation, 5 (1), 9.

[18] Oro, O. U., \& Alagidede, P. (2018). The Nature of FinanceGrowth Relationship: Evidence from a Panel of Oil-Producing Countries. Economic Analysis and Policy. Available at SSRN 3190069.

[19] Schumpeter, J. A. (1912). 1934. The theory of economic development.

[20] Swiston, A. (2008). A US financial conditions index: putting credit where credit is due (No. 8161). International Monetary Fund.

[21] Wang, S., Xu, F., \& Chen, S. (2018). Constructing a dynamic financial conditions index by TVP-FAVAR model. Applied Economics Letters, 25 (3), 183-186. 